\title{
THEOLOGICAL REFLECTIONS ON EMPIRE
}

Author:

Allan A. Boesak

\section{Affiliation:}

'Faculty of Theology, Stellenbosch University,

South Africa

Correspondence to:

Allan A. Boesak

e-mail:

boesak@mweb.co.za

\section{Postal address:}

Postnet Suite 285, Private

Bax X15, Somerset West

7130 , South Africa

\section{Keywords:}

empire; colonialism

globalisation; Accra

declaration; World

Alliance of Reformed

Churches

Dates:

Received: 21 Aug. 2008

Accepted: 10 June 2009

Published: 06 Nov. 2009

How to cite this article:

Boesak, A.A., 2009,

'Theological reflections

on empire', HTS Teologiese

Studies/Theological Studies

65(1), Art. \#291, 7 pages.

DOI: 10.4102/hts.v65i1.291

This article is available at:

http://www.hts.org.za

(c) 2009. The Authors. Licensee: OpenJournals Publishing. This work is licensed under the Creative Commons Attribution License.

\section{ABSTRACT}

Since the meeting of the World Alliance of Reformed Churches in Accra, Ghana (2004), and the adoption of the Accra Declaration, a debate has been raging in the churches about globalisation, socio-economic justice, ecological responsibility, political and cultural domination and globalised war. Central to this debate is the concept of empire and the way the United States is increasingly becoming its embodiment. Is the United States a global empire? This article argues that the United States has indeed become the expression of a modern empire and that this reality has considerable consequences, not just for global economics and politics but for theological reflection as well.

\section{Discerning the signs of the times}

\section{INTRODUCTION}

'Discerning the signs of the times' is the framework within which the General Council of the World Alliance of Reformed Churches (WARC) has chosen to set its deliberations, out of which flowed 'The Accra Confession' ( 2004). The times we live in, the document argues, are times of great urgency, global economic injustice and ecological destruction. The times depict a 'scandalous world' of harsh, utterly shocking and growing inequalities across the world among and within nations, resource-driven wars, poverty and disease, of which the most vulnerable victims are women and children. These are times of wanton, profit-driven destruction of the earth and rapacious plundering of her resources, which all are part of 'a crisis directly related to the development of neo-liberal economic globalization' (The Accra Confession 2004:para. 9).

This unjust global economic system is defended and protected by political and military might and has become a matter of life and death. It is an overwhelming system based on the belief that:

unrestrained competition, consumerism, unlimited economic growth and accumulation of wealth is best for the whole world; (that) ownership of private property has no social obligation; that capital speculation, liberalization and deregulation of the market, privatization of public utilities and natural resources, unrestricted access for foreign investments and imports, lower taxes and the unrestricted movement of capital will achieve wealth for all; social obligations, protection of the poor and weak, trade unions and relationships between people are subordinate to the processes of economic growth and capital accumulation.

(ibid. 2004:para.9)

Note that these are indicated not just as 'basic principles' or mere 'realities' but as 'beliefs'. This is therefore no less than an

ideology that claims to have no alternative, demanding an endless flow of sacrifices from the poor and creation. It makes the false promise that it can save the world through the creation of wealth and prosperity, claiming sovereignty over life and demanding total allegiance which amounts to idolatry.

(ibid. 2004:para.10)

Depicting these realities as the signs of our times, the document comes to the conclusion that the world, and hence the Christian church, is once more faced with the challenge of empire. Our reality is an imperial reality. In using the term 'empire', the document declares, 'we mean the coming together of economic, cultural, political and military power that constitutes a system of domination led by powerful nations to protect and defend their own interests.' In short, the Christian church today is facing 'a new Rome' (ibid. 2004:para.11).

It is clear that the statements from the document I have quoted are not meant to be read as economic or political observations only; they also have theological import. The language in which points 9 and 10 are couched argues for this. At point 11, however, where the word 'empire' is explicitly used, there is no attempt at a theological understanding. So three questions arise:

- Is the Accra Confession right in asserting that we are, in fact, dealing with an empire and an imperial reality?

- Can we speak theologically about empire and is there something in the Scriptures and the tradition of the church that can help us in this?

- What should the stance of the Christian church be if indeed we are facing an empire, a new Rome?

\section{A new Rome}

We shall have to begin with the assertion that the spirit of discernment shown by the Accra Confession has proved to be correct. The understanding of empire, furthermore, as the relationships of political control imposed by some political societies over the effective sovereignty of other political societies' is borne out by scholars as well as political and military analysts (Doyle 1986:19; Taylor 2006). The allimportant link between human suffering and ecological disaster is also confirmed.

For the first time since the rise of human civilisation, the history of which has to a large extent been the history of empires, one empire is now on the verge of becoming a truly global empire, an empire with no borders. For the first time as well, we are aware that even if the human race avoids self-annihilation through nuclear weapons, it is on a trajectory toward self-annihilation through human-caused climate 
change. These two crises are, moreover, closely related because the nation that is seeking to become the world's first borderless empire - the United States of America - is also the nation that, precisely through its imperialist policies, is the primary threat to the survival of the human species (along with that of other species as well) (Griffin, Cobb, Falk \& Keller 2006; Moe-Lobeda 2001).

While Griffin et al. (2006) write from within the USA context in order to 'register our protest against this empire', someone like Jonathan Freedland does not. He simply dispassionately observes the following:

So Americans may be more Roman than we realize, with garrisons in every corner of the globe. But there the similarities only begin. For the US's entire approach to empire looks quintessentially Roman. It is as if the Romans bequeathed a blueprint for how imperial business should be done today and Americans are following it religiously.

(Koshy 2006:337)

There was a time when the word 'empire' was considered controversial and was even anxiously avoided if not actively resisted by politicians and scholars alike. Americans saw themselves as uniquely anti-empire and anti-colonial, distinctly different from their European counterparts. But all this has changed. The media as well as respected analysts on both the left and the right are now referring to 'American empire' approvingly as the dominant narrative of the 21st century. The military victory in Iraq seems to have confirmed a new world order (Koshy 2006:337): 'Not since Rome', observed Joseph Nye, Dean of Harvard University's Kennedy School of Government, 'has one nation loomed so large above the others. Indeed the word "empire" has come out of the closet".

Michael Ignatieff, who wrote what is considered to be the seminal essay on empire, made the point quite convincingly: 'What word but empire', he asks, 'describes the awesome thing that America is becoming?' He drives the point home:

It is the only nation that polices the world through five global commands, maintains more than a million men and women at arms in four continents, deploys carrier battle groups on watch in every ocean, guarantees the survival of countries from Israel to South Korea, drives the wheels of global trade and commerce and fills the entire planet with its dreams and desires.

(Koshy 2006:335)

In contrast to this somewhat romantic vision of the American empire, the policy papers of the Defence Department, the State Department and the neo-conservative think tanks who provide the intellectual arguments for the Bush Doctrine are much more stark and dispassionate. Steven Peter Rose, Director of the Olin Institute for Strategic Studies at Harvard University, writes as follows:

The United States has no rival. We are militarily dominant around the world.... Our goal is not combating a rival, but maintaining our imperial position and maintaining imperial order... Planning for imperial wars is different from planning for conventional wars.... The maximum amount of force can and should be used as quickly as possible for psychological impact, to demonstrate that the empire cannot be challenged with impunity... Imperial wars end, but imperial garrisons must be left in place for decades to ensure order and stability.... Finally, imperial strategy focuses on preventing the emergence of powerful hostile challengers to the empire: by war if necessary, but by imperial assimilation if possible.

(Koshy 2006:337)

Stephen Rose worked previously for the US Department of Defence as well as for the National Security Agency and was a founder member of the Project for the New American Century, one of the key builders for the ideological foundations of the Bush Doctrine. In just this one quotation the word 'imperial', used totally unapologetically, appears no less than seven times. Not just progressively thinking theologians and commentators have highlighted this pattern of thinking that has become the bedrock of President Bush's philosophy and policies but so have more conservative scholars such as Andrew Bacevich (2002). The great value of Bacevich's work is not just that he analyses the realities of American empire but that he shows that it is not something that was either 'thrust upon' the US by historic determination or that the US has accidentally 'stumbled upon'. It was, he argues, the serious and deliberate long-term goal of successive US administrations from Woodrow Wilson at the beginning of the 20th century to Bill Clinton at its end, to George W. Bush in the new millennium.

David Ray Griffin provides an impressive list of sources now dealing with the realities of American empire, its military, political, cultural, juridical and economic reaches and the consequences of these, as well as the ideological thinking behind it all (Griffin et al. 2006:161).

My point is that denial of the existence of American empire is no longer feasible. In this regard, the Accra Confession is absolutely correct. It is just as clear that American foreign policy, 'representing the deterritorialization of a hegemonic state power, coupled with the assumption of postcolonial prerogatives with respect to law and order' as Richard Falk (2006:50) calls it, in its manifest global manifestations is imperial in its design as well as in its reality. The exercise of American power on the scale we experience today cannot be fully understood except as a deliberate project aimed at accruing wealth and influence and military might. To persist in pretending otherwise was and is more than ever a 'grand illusion' as William Appleman Williams wrote already in 1980, 'the charming belief that the United States could reap the rewards of an empire without paying the costs of empire and without admitting that it was an empire' (Bacevich 2002:243).

There is no purpose to be served in denying the facts, even though they might not be cause for celebration, Andrew Bacevich concludes. He speaks to Americans, but he also speaks to us. 'Like it or not, America today is Rome, committed irreversibly to the maintenance and, where feasible, expansion of an empire that differs from any empire in history' (Bacevich 2002:244).

\section{Through the eyes of the powerless}

The Accra document is at pains to make the point that it reads history through the eyes of the powerless and suffering people. From this point of view our current world order might be a New World Order for the powerful, opening up opportunities hitherto unknown for the beneficiaries of empire, but for the suffering masses it is a disorder, a cruel and unjust system of domination and exploitation. This is perhaps part of the often-unarticulated problem underlying the current tensions in the debate amongst the churches.

One of the key lessons learnt from the history of liberation theology is the centrality of contextuality, the significance of 'where one stands' when thinking about and discussing these matters. This is not only true of the history of theology for as long as we can remember; it is also true for the Bible, both for the way in which biblical narratives are being told and for the way in which those narratives are being read, understood, interpreted and retold. The context of telling is as important as the context of retelling. Hence it is vital to hold onto the significance and meaning of this important sentence.

It will serve us well to remember that the reality of globalisation is not thinkable without the reality of the forces that drive it: global capitalism first among them, closely followed by military, political and cultural forms of domination. They are indeed systems of mutual reinforcement and cohesion coming together to realise the aims of self-interest on behalf of the rich nations of the world and the rich elite in the poor countries. The combined substance of these forces is what is called 'empire'. 'Global capitalism is a system of immense power,' Jonathan Sacks writes, 
from which it has become increasingly difficult for nations to dissociate themselves. More effectively than armies, it has won a battle against rival systems and ideologies, among them fascism, communism and socialism, and has emerged as the dominant option in the twenty-first century for countries seeking economic growth.

(Sacks 2006:28)

Not everyone is convinced that particularly fascism has been overcome. In fact, strong arguments are being made that American democracy itself is losing territory to fascist tendencies (Falk 2006: 44-68). Sacks goes on:

But globalization has immensely differential and destabilizing effects. Its benefits are not spread evenly. There are winners and losers, within and between countries... The average American consumes five times more than a Mexican, ten times more than a Chinese, 30 times more than an Indian. There are 1.3 billion people - 22 per cent of the world's population - living below the poverty line; 841 million are malnourished; 880 million are without access to medical care. One billion lack adequate shelter; 1.3 billion have no access to safe drinking water; 2.6 billion go without sanitation. Among the children of the world, 113 million - two-thirds of them girls - go without schooling; 150 million are malnourished; 30,000 die each day from preventable diseases.

(Sacks 2006:29)

Sacks goes on to show the distressing figures regarding life expectancy and the alarming drop in per capita incomes in poor countries. The huge gap between the rich and the poor, as vividly portrayed by someone like Sampie Terreblanche (2002) for South Africa, for example, is perhaps best summarised by Sacks's laconic remark: 'By the end of the millennium, the assets of the world's three richest billionaires were more than the combined wealth of the 600 million inhabitants of the leastdeveloped countries' (Sacks 2006:29).

What is true for rich and poor countries separately is also true for within rich and poor countries. The third world is everywhere (Boesak 2005:86-88; Sacks 2006:29-30;). In a country like South Africa, the contrast between the poor masses and the enormously rich elite whose wealth has been accumulated only in the last decade or so is no less than shocking.

The immense power of economic globalisation can be seen also in the growth of the power of transnational corporations and the role of international financial institutions such as the World Bank and the International Monetary Fund that are in constant competition with the power and competencies of national governments (Boesak 2005:77-86). The power of these entities does not only lie in their own economic strength but also in the fact that they, unlike governments of national states, are not accountable to the voting public but only to their boards and shareholders and that they are either in the service of the rich nations, beholden to them or in collusion with them (Boesak 2005:88-91).

So while Jonathan Sacks speaks somewhat euphemistically of the benefits of globalisation not being spread evenly, the 1997 United Nations Development Program report, States of Disarray, is far less so: Globalisation is thus proceeding apace but largely for the benefit of the more dynamic countries in the North and (the rich elites) in the South. For the poor countries, the unreal and discredited optimism of the trickle-down theory - the rising tide that is supposed to automatically lift all boats - seems to be firmly in place. But 'the yachts and ocean liners are indeed rising in response to new opportunities, but the rafts and row boats are taking on water - and some are sinking fast' (Boesak 2005:90). The conclusion is blunt: 'The new law', the report writes, 'is the law of the jungle: only the fittest can survive' (Boesak 2005:91).

This is what the Accra Confession means when it speaks of a 'scandalous world', and this is what empire represents to the churches that represent the poor communities of the world. For them, the empire and imperial power are not a 'kind of welfare imperialism, empire building for noble ends rather than for such base motives as profit and influence' as Ronald Steele argued in his 1967 work Pax Americana (Griffin et al. 2006:4).

This may leave us incredulous, but such surprising attitudes run deep in the American psyche despite the historical evidence. The story of American imperialism, Griffin argues, is not a story of a benign empire with 'the most noble motives and with the most generous impulses' (Griffin et al. 2006). That story needs to begin with the displacement of Native Americans and the extermination of about 10 million of them. It is a story that would need to deal with the increasing number of invasions of countries from Guatemala and Chile, El Salvador and Nicaragua, Cuba and the Philippines and many more. It would have to explain America's installation and support of right-wing regimes in Italy, Japan, Greece and France and of murderous dictatorships in South Korea, the Philippines, El Salvador, Guatemala and Africa. This would be a story of the economic policies behind the interventions and America's posture with regard to nuclear weapons (Griffin et al. 2006:4-5). It is, as Griffin says, 'a long story' but one that the people of the South have not just heard; they have lived it.

It is not just economic policies in the official form and ramifications that we are talking of here. We are also speaking of the covert economic tactics designed to extort, blackmail and plunder third world countries for the benefit of transnational corporations and the rich countries that benefit from these operations.

Thanks to John Perkins, author of the quite startling and revealing book Confessions of an Economic Hit Man (2004), we are now aware of so-called economic hit men employed by big international corporations and who simultaneously serve international monetary agencies. They serve a small corporate elite whose influence is pervasive, no matter who wins formal elections, and whose goals are ever more profit and power: 'the preservation and extension of an empire':

Economic hit men are highly paid professionals who cheat countries around the globe out of trillions of dollars. They funnel money from the World Bank, the U.S. Agency for International Development (USAID), and other foreign "aid" into the coffers of huge corporations and the pockets of a few wealthy families who control the planet's natural resources. Their tools include fraudulent financial reports, rigged elections, payoffs, extortion, sex, and murder. They play a game as old as empire, but one that has taken on new and terrifying dimensions during this time of globalisation. I should know; I was an Economic Hit Man. ${ }^{1}$

(Perkins 2007:4)

Such words strip us of our ignorance as well, confront us with immense ethical problems and compel us to probe deeper into the realities we live with.

\section{Farewell to innocence}

Farewell to Innocence is the title of the dissertation I wrote in 1976. It was meant then to help black and white people in South Africa to understand what it meant to live in a world forged by our 'pseudo-innocence', a childishness that distorts our reality and closes our eyes to matters we find too horrendous to contemplate, causing us to make a virtue out of powerlessness, weakness and helplessness. It is an innocence that leads to a helpless utopianism - either an idealisation of the present bad situation or escapism

1.Hiatt, S. (ed.), 2007, A Game as old as Empire: The Secret World of Economic Hit Men and the Web of Global Corruption. This valuable and informative book deals with such issues as 'the web of control of global empire'; the third world 'debt trap'; the secret world of off-shore banking; the corruption regarding Nigeria's oil; 'hijacking Iraq's oil reserves'; and others. It reiterates the point we have made earlier regarding the growing threat to the power of nation states vis-á-vis transnation regarding the growing threat to the power of nation states vis-a-vis transnational financial institutions: The world is now more multipolar and mercantile, with China and Europe emerging to compete with the US. Empire is heavily driven by multinational corporations whose interests transcend those of any particular nationstate. The implications of the actions described in the book are staggering and will have an impact on generations to come. It is a world of which the church is completely ignorant, but it is nonetheless the real world in which we live, and now we can longer act as if we don't. The authors wrote their stories because they believe 'we must begin today to recreate the world corporatocracy has inflicted upon us'. 
into a 'better' world than the present one. This pseudo-innocence cannot come to terms with the destructiveness in oneself or in others and hence it actually becomes self-destructive. It is this innocence that uses the 'ideal' to blind people so that they do not see the atrocities of the present. It blinds, paralyses and cunningly uses all means at its disposal to cover up and rationalise guilt and sin. It is an innocence that, for its own justification, does not include evil. It therefore becomes demonic.... It effectively blocks off all awareness and therefore the sense of responsibility.

I think this paradigm has once again proved very apt indeed for the situation in which we find ourselves today. This time, however, its impact is much broader than the white/black context of South Africa 30 years ago. We should apply this concept to the global situation in which we live today, a situation of imperial power and reality and the response of the church to that reality.

We began this part of our discourse with reference to the curious belief in the goodness of the American empire Ronald Steele spoke of and Griffin responded to. That belief still exists today and in a way that many are finding increasingly alarming. It is more than just an attitude; it is indeed a belief in a unique American innocence that responds, in its depth and manifestations, exactly to my description of pseudo-innocence and that, in the post9/11 world especially but not for the first time, has been raised to an article of faith in the United States. It is this faith contrasted with the reality of American deeds in the world that has caused Rosemary Radford Ruether (2007:1) to speak of 'the two faces of America', an America with a 'double identity'.

It is because the American people hear their leaders expressing the right concern at the right time... they see them laughing and telling jokes, see them with their families, hear them speak of God and love, of peace and law, of democracy and freedom - it is because of these things that the idea that our government has done to the world's huddled masses what it did to the Seminoles has such a difficult time penetrating the American consciousness. It's as if America has an evil twin.

(Ruether 2007:1)

Ruether points out that American leaders know that they 'touch a deep root of national faith when they use these words' but in actual fact they often do something very different. Thus these unacceptable realities must be cloaked 'in the language of national values rooted in a belief that America is uniquely innocent and good, chosen by God to defend freedom and democracy around the world' (Ruether 2007:1-2).

Thus Ruether exposes the pseudo-innocence of American politics and she is not the only one. In a brilliant paper entitled Faith-based war, from 9/11 to catastrophic success in Iraq, Walter Herbert (2006) explored America's 'national mythology' and how that particular religious system 'embraced by the Bush administration as that version participated in the mounting and execution of the invasion of Iraq'.

Herbert (2006:5) shows how at the prayer service at the National Cathedral 'America the Beautiful', the 'pre-eminent national hymn', invoked the

sacred America that was violated in 9/11 and defines the bond of shared belief through which the administration established justification for its war policy in the minds and hearts of the public....

(Herbert 2006:6)

'The myth of American invulnerability was joined to a myth of American virtue, as if the nation deserved the divine favour shown it...' (ibid.). The hymn, as read by most Americans, inspires a vision 'incorporating biblical and theological themes, which imagines that America is hated by evildoers because it is good' (Herbert 2006:11). There was 'nothing for Americans to learn about ourselves from this disaster, except that we'd been horribly wronged... there was no precursory failure on our part at all...'. In classical Christian theology, Herbert writes,

Satan hates the goodness of God because it is goodness. Likewise here: the attacks were motivated by hatred of American virtues. Against this shadowy, shape-shifting evil, no evidence is necessary, no debate required; it is obvious to the eye of faith.

(Herbert 2006:12)

All this and more goes into the making and sustaining of American innocence. So, from George W. Bush - 'We are serving in freedom's cause, a cause that is the cause of all mankind' to Michael Ignatieff - 'America's empire... is a new invention... a global hegemony whose grace notes are free markets, human rights and democracy.... It is the imperialism of good intentions (Griffin et al. 2006:9-10) - America's innocence is reaffirmed. Rosemary Ruether shows how deep it runs in politics:

Most American politicians are deeply self-deluded by their own rhetoric. Indeed to combine being both practitioners of real Politik and also self-deluded believers in the rhetoric of America's messianic role is the basic requirement of an effective American politician.

(Ruether 2007:2)

The belief in the goodness of the empire by those who benefit from it and that it is therefore good for those colonised and exploited by it is of course not new. The Romans believed the same. Their empire was universal and good and willed by the gods. The gods favoured them because of their piety and justice and an empire based on those values could only be a good thing, writes Joerg Rieger (2007:27-28), who quotes the words of Cicero: 'Do we not observe that dominion has been granted by Nature to everything that is best, to the great advantage of what is weak?' And in the same vein we hear Plutarch: 'An essential difference between (the Roman empire) and other ancient empires is that the Romans govern free men, not slaves' (Rieger 2007:27-28). This sounds like a serious disconnect from reality, but it is no worse than the reality observed by Ruether:

American national leaders are often believers in their own ideological rhetoric. They both pursue murderous policies motivated by what they see as American self-interest and also manage to sincerely believe that they are serving the best interests of these colonized and exploited people as well.

(Ruether 2007:2)

The time has come for Christians to realise that we cannot condone, ignore or suffer from this disconnect. This selfdelusion is not just politically problematic; it is sinful. It is not for us to ponder the nature of this self-delusion and to pander to it; it is for us to expose, confront and resist it. It is not the self-delusion as psychological phenomenon that concerns us; it is the consequences that others must live with that call forth our response.

There is, however, another aspect of this pseudo-innocence that is pertinent to our discussion. The imperial reality we are speaking of might be an American empire, but it is not America's alone. It is an empire that is, the Accra Confession states, 'a coming together of economic, cultural, political and military power that constitutes a system of domination led by powerful nations' (The Accra Confession 2004:para. 11). German ecumenical theologian Ulrich Duchrow (2006:392) writes that before America's prominent global role, renowned Swedish sociologist Johan Galtung already spoke of the European Community as a 'Super Power in the making', led first by the former six colonial powers but presently, however, led by the power of transnational corporations.

'The classical period of European imperialism at the end of the 19th century', says Duchrow (2006:391), 'was developed as a hegemonic political and military security system for the foreign investments of European capital in profitable regions of the world'. After the USA took over this model and role, the present policy of the EU has been to try to establish Europe as what Duchrow (2006:391) calls a 'sub-empire, partly in competition, partly in alliance with the USA'. At present European churches 
are 'unwilling to face the reality of the EU in the context of global empire'. Duchrow's historical and political analysis leads him to conclude that it can be said that the EU is part of the neoliberal capitalist US empire, partly competing with the US in this framework' (Duchrow 2006:393).

This view is underscored by Benn Steil (2008), director of international economics at the Council on Foreign Relations, who expresses deep concern at the sliding position of the dollar vis-a-vis the euro and explains 'how the rise of the euro threatens America's dominance':

'As the dollar continues its relentless six-year slide against the euro and other main currencies, the question is being asked more and more: what would it mean if the dollar ceded its global dominance to the euro? ${ }^{2}$

Steil asks what this would mean also for America's political power in the world. He worries about the clout of the dollar to buy US influence in terms of international aid, foreign assistance and purchasing power, 'whether for humanitarian, economic or military purposes'. He mentions the US's power to put pressure on countries such as Iran through its control over the dollar and then states,

The US would likewise lose influence over both friends and enemies facing financial problems, as they would be looking increasingly to Europe for euros rather than to America for dollars.

Steil concludes, 'This can only lead to greater damage to America's prosperity and global influence.' But the churches seem to fail to recognise this. What might be the reasons for the position of the European churches? Duchrow spells out his 'hunch':

Until a short while ago the Europeans could leave the dirty job of protecting Western exploitation of the world's resources to the USA, which up to recently disguised its imperial acts by utilizing proxies. In the shadow of the super power Europeans could do profitable business. Now the USA, under the Bush administration, is taking off the mask and acting openly and brutally itself as an imperial power. And furthermore, the EU is beginning to form itself openly as an imperial power. This is shaking the illusion of the West being a social and democratic market society which up to now was the basis for the positive relationship between the churches and the political and economic system and elites. Realizing this reality would bring the churches into basic conflict with the powers of the existing system which they fear because of the privileges they still enjoy in the old pattern of Constantinian church-state relationships.

(Duchrow 2006:393-394)

Duchrow (2006:391) describes this stance as an 'illusionary consciousness' that makes it hard for the churches to face reality and find 'a new ecumenical vision'. In other words, European churches share to a great extent the affliction of pseudo-innocence we have identified in the United States.

In 1977 I wrote, pertaining to the South African situation, 'It is absolutely imperative for the oppressors to preserve their innocence just as it is imperative for the oppressed to destroy it' (Boesak 1987:5). Likewise the globalised poor today do not have the luxury to allow that innocence to continue to exist. Not in others with powers of global destruction, not within themselves nurturing their imagined powerlessness, nor in their own societies with regard to the complicity of their own elites. It is indeed a matter of life and death. African-American writer James Baldwin made it clear long ago: 'But it is not permissible that the authors of devastation should also be innocent. It is the innocence which constitutes the crime' (Boesak 1987:1).

2.See Steil, B., 2008, 'How the rise of the Euro threatens America's dominance',
Financial Times (London), 23 April, viewed 1 September 2009, from http://www. ft.com/cms/s/0/428e637e-10d1-11dd-b8d6-0000779fd2ac.html.

\section{This is mine to decree...}

It is crucial for us to realise that throughout the ages imperial reality has been an all-encompassing one. It was not merely military or political; it was above all a religious reality. Religion was not a private individual matter; it was a civic and public practice, visible everywhere. Imperial theology was the unmissable foundation upon which it all rested. Basic to and defining of Roman imperial theology was the claim that Rome ruled its empire because the gods willed Rome to rule the world (Warren 2001:20).

The Roman empire espoused a world view, a 'myth of supernatural character... beyond military, economic and sociopolitical bases of power', a

religion that identifies and sanctions those who order, rule over and benefit from the empire and creates and confirms the subordinate roles and compliant responses of those who are ruled.

(Warren 2001:20)

Political ideology was formulated in theological terms and expressed through cult and ritual, the centre of which was the emperor, at first the divine instrument of the gods but later himself a god. Hence the emperor cult in all its manifestations became the public and civic expression, the foundational theological justification and legitimation, of the empire. In the person of the emperor was the divine presentation of the relationship between the ruler and the ruled, the god-willed submission of the empire's subjects to such an exalted and divinely legitimated emperor. Rome's power and military might and glory, Rome's wealth and political wisdom, Rome's ability and right to rule nations - it is all personified by the emperor.

Nero, we know, did not claim divinity for himself, but in him already the seeds of divine awareness and power are budding. Seneca has Nero say,

Have I of all mortals found favour with heaven and been chosen to serve on earth as vicar of the gods? I am the arbiter of life and death for the nations; it rests in my power what each man's lot and stake shall be: by my lips Fortune proclaims what gifts she would bestow on each human being; from my utterance peoples and cities gather reasons for rejoicing... what nation shall utterly be destroyed, which banished...what kings shall become slave...what cities shall rise and which shall fall - this is mine to decree.

(Warren 2001:11)

After Nero, Rome's emperor cult becomes the bedrock of all imperial expression. Imperial poets and priests shape the rituals. For Statius, Domitian is the "Lord of the earth", "ruler of the nations and mighty sire of the conquered world". For Martial Domitian is 'the world's sure salvation', his very being 'manifests divine presence' (Warren 2001:2526). 'Hail, our Lord!' the poets sing as Caesar enters the temple,

Glory, victory to the Lord of the earth! Invincible, crowned with glory, power and honour. Holy, blessed, incomparable art thou; worthy alone to enter thy kingdom. Come, O Lord, do not delay. Come!

(Boesak 1987:53)

This is the idolatry that the first Christians could not accept and that so much of the New Testament so consistently resists. This is the imperial reality in which first the Jesus movement and then the Christian church came into being, lived and worked and testified and that lends such enormous significance to the titles the Christian church in the beginning accorded Jesus. Not Caesar but Jesus was Lord. Not the emperor but Jesus is the true Saviour of the world. It is not true that the emperor holds life in his hands; our lives are in the hands of the Living One. So when New Testament writers speak of Jesus as Lord, it is a direct challenge to the one on the throne of Rome who calls himself Lord and God. When they call the slaves and people from the lower classes who form the Christian communities 'a chosen race, a royal priesthood, a holy nation, God's own people' (1 Peter 2:9), it is a direct correction of the empire's social-economic 
stratification and political hierarchy that places the aristocracy at the top and slaves at the bottom. When Jude ends his epistle thus, 'To the only God our Saviour, through Jesus Christ our Lord, be glory, majesty, power and authority, before all time and now and forever' (Jude 1:25), he pronounces a scathing critique on Rome's imperial theology and the emperor's divine presumptions. So is John of Patmos's worship of Jesus as 'the Alpha and Omega, the beginning and the end, the first and the last'. A stronger denunciation of the blasphemous claims of the emperor is hardly thinkable (Boesak 1987; Horsley 2003; Warren 2001).

Paul's famous theological construct of the church in Galatians 3:9 and 10, if read with this in mind, becomes a turn-around of the logic of empire, and in marvellous ways he overturns that logic several times (Horsley 1997, 2000). This is not accidental but deliberate, not of marginal importance but critical for understanding Paul and the stance of the early Christian communities. The same is true for the Gospels. The evidence of the imperial presence and critique of and resistance to that presence is everywhere, if we but care to look. Liberation theology began to probe these possibilities 30 years ago, but there is a whole new approach to New Testament studies and theology finally developing that takes all this into account and opens exciting paths to new understandings of the New Testament (Boyarin 1994; Crossan 1991; Elliot 1994; Horsley 2000).

It is with these insights that we must arm ourselves when we think about the challenges of imperial reality today. We shall keep in mind that while emperor worship as such seems to be out of vogue, the identification of the empire with God and God's will is still very much alive and in fact, as Herbert has shown, the religious mythology in support of empire is very much at the heart of America's current self-understanding.

The similarities abound. First-century Jewish historian Josephus has Agrippa declare that 'without God's aid so vast an empire could never have been built up' (Warren 2001:21). There is an uncanny resemblance with US Vice President Dick Cheney's words in his 2003 Christmas card, quoting Benjamin Franklin: 'And if a sparrow cannot fall to the ground without His notice, is it probable that an empire can rise without His aid?' This use of the 'Divine Reality' as Griffin calls it is 'profoundly wrong, even idolatrous' (Warren 2001:vi)

The idolatry lies not only in the 'worship' of consumerism, money and goods and the way in which profits are placed above people but also in the way in which America identifies itself with God and goodness, as we have seen. This identification with goodness and God almost automatically calls up a conjured reality of evil on the other side. Hence the talk of 'the axis of evil', the 'war against evil' and the war on terror as the war to bring 'an end to evil'. So the suggestive title of a book by Richard Perle and David Frum (2003), two of 'Washington's most influential insiders' - An End to Evil: How to Win the War on Terror. The 'evil' is Islamist extremism, the danger from North Korea, the threat to America's homeland security. The war against this evil is 'our generation's great cause'. The end is not to just contain or 'manage' this evil, but to win. 'There is no middle way: it is victory or holocaust' (Perle \& Frum 2003:9).

It follows that there is thus an easy demonisation of others, especially non-white third world people, especially Arabs, that leads to a dehumanised other, an evil presence to be eliminated. And since the enemy is not persons but 'evil', all and any means are justified; there is no possibility for error on the side of those who represent goodness. This theological stance harbours within itself another ideological trait: It closes itself off from all self-criticism or correction. It takes upon itself an attribute ascribable only to God: that of sinlessness. Herbert (2006:12)

3.See 'Dick Cheney's Empire Christmas Card', 2003, viewed on 16 September 2009 from www.mindfully. org/.../2003/ speaks of 'the moral luxury of bypassing any question about American culpability...'.

Globally, we are confronted with an ideology that claims to be all powerful, without any alternative and hence without any possibility of challenge or change.

It makes the false promise that it can save the world through the creation of wealth and prosperity, claiming sovereignty over life and demanding total allegiance, which amounts to idolatry.

(Accra Confession 2004:para. 10)

Like Moloch it demands 'an endless flow of sacrifices from the poor and creation' (ibid.). The church is called to resist all these new forms of idolatry, for these have enormous moral, political, economic and theological consequences. It seems to me that we shall have to begin by allowing for a new understanding of the imperial context of the New Testament as well as the ways in which traditional Christian theology, as shaped by Western Europe and Euro-American thinking and interpretation, have left us ill-prepared for dealing with the theological, political and economic realities the church is facing today. We need, in other words, a process of 'decolonisation', a process that will help us undo the domestication of Jesus, Paul and the writings of the New Testament that has proved so harmful in the history of Western Christianity.

We shall have to explore further the patterns of 'reframing and resistance' that Joerg Rieger (2007:27-28) has identified 'from Paul to post colonial times'. Secondly, we shall have to engage in hard political and economic analysis of our imperial realities today and of the manifestations of globalisation and its impact on the world and the communities where we live, work and worship and on the life of the church. Over against the 'false promises' of empire we shall have to proclaim the promises of God in Jesus Christ that are diametrically opposed to the promises of empire. Thirdly, we shall have to deny claims that the reality of empire is so overwhelming as to be unchallengeable and unchangeable as if it were ordained by divine sanction. We shall have to resist all absolutist claims. Fourthly, we shall have to resist the insistence on our powerlessness. We shall, rather, have to insist on the truth of the Confession of Belhar (September 1986):

We believe that God's life-giving Word and Spirit will enable the church to live in a new obedience which can open new possibilities of life for society and the world.

(Confession of Belhar 1986:para. 3)

So we shall have to shape ways of resistance beginning from our own understanding of the Christian faith and its calling for the times in which we live. And, finally, we shall have to find new ways of obedience, of being in solidarity and of creating communities of life and witness in the world.

This, in my view, is a most appropriate way of discerning the signs of the times and acting upon that discernment.

\section{REFERENCES}

Bacevich, A., 2002, American empire: The realities and consequences of US diplomacy, Harvard University Press, Cambridge.

Boesak, A.A., 1987, Farewell to innocence, 4th edn., Orbis, New York.

Boesak, A.A., 1987, Comfort and protest: The apocalypse from a South African perspective, Westminster, Philadelphia.

Boesak, A.A., 2005, The tenderness of conscience: African renaissance and the spirituality of politics, Stellenbosch University Press, Stellenbosch.

Boyarin, D., 1994, A radical Jew: Paul and the politics of identity University of California Press, Berkeley.

Crossan, J.C., 1991, The historical Jesus: The life of a Mediterranean Jewish peasant, HarperCollins, San Francisco.

Doyle, M.W. 1986, Empires, Cornell University Press, London.

Duchrow, U., 2006, 'An ecumenical vision for a community of life in Europe', Reformed World 56(4), 391-403. 
Elliot, N., 1994, Liberating Paul: The justice of God and the politics of the apostle, Orbis, Maryknoll.

Falk, R., 2006, 'Slouching toward a fascist world order', in D.R. Griffin, J.B. Cobb Jr, R.A. Falk \& C. Keller (eds.), The American empire and the commonwealth of God: A political, economic, and religious statement, pp. 44-68, Westminster John Knox, Louisville.

Griffin, D.R., Cobb, J.B. Jr, Falk, R.A. \& Keller, C. 2006. The American empire and the commonwealth of God: A political, economic, and religious statement, Westminster John Knox, Louisville.

Herbert, W., 2006, 'Faith-based war, from 9/11 to catastrophic success in Iraq', paper presented at the Liberation Theology in the 21st Century conference, Baylor University, Waco, 11-13 October 2006.

Hiatt, S. (ed.), 2007, A game as old as empire: The secret world of economic hit men and the web of global corruption, BerrettKoehler, San Francisco.

Horsley, R.A. (ed.), 1997, Paul and empire: Religion and power in Roman imperial society, Trinity Press, Harrisburg.

Horsley, R.A. (ed.), 2000, Paul and politics, ekklesia, Israel, imperium, interpretation, Trinity Press, Harrisburg.

Horsley, R.A., 2003, Jesus and empire: The Kingdom of God and the new world disorder, Fortress Press, Minneapolis.

Koshy, N., 2006, 'The global empire: An overview', in D.R. Griffin, J.B. Cobb Jr., R.A. Falk \& C. Keller (eds.), The American empire and the commonwealth of God: A political, economic, and religious statement, pp. 335-337, Westminster John Knox, Lousville.

Moe-Lobeda, C., 2001, Healing a broken world: God and globalization, Fortress Press, Minneapolis.

Office of Theology and Worship, Presbyterian Church, USA, 1986, Confession of Belhar, viewed 1 September 2009, from www.pcusa.org/theologyandworship/confession/belhar. pdf

Perkins, J., 2004, Confessions of an economic hit man, BerretKoehler, San Francisco.

Perkins, J., 2007, 'Introduction: New confessions and revelations from the world of economic hit men', in S. Hiatt (ed.), A game as old as empire: The secret world of economic hit men and the web of global corruption, pp. 1-12, Berrett-Koehler, San Francisco.

Perle, R. \& Frum, D., 2003, An end to evil: How to win the war on terror, Random House, New York.

Rieger, J., 2007, Christ and empire: From Paul to postcolonial times, Fortress Press, Minneapolis.

Ruether, R.R., 2007, America, Amerikka, elect nation and imperial violence, Equinox, London.

Sacks, J., 2006, The dignity of difference: How to avoid the clash of civilizations, Continuum, London.

Steil, B., 2008, 'How the rise of the Euro threatens America's dominance', Financial Times (London), 23 April, viewed 1 September 2009, from http://www.ft.com/cms/ s/0/428e637e-10d1-11dd-b8d6-0000779fd2ac.html.

The Accra Confession, 2004, 'Covenanting for justice in the economy and the earth - The Accra Confession', viewed 1 September 2009, from http://warc.jalb.de/warcajsp/side. jsp?news_id $=181 \&$ part_id $=0 \&$ navi $=1$.

Taylor, M.L., 2006, 'Theology and global empire today', Reformed World 56(4), 415-432.

Terreblanche, S., 2002, A history of inequality in South Africa, 1652-2002, Natal University Press, Pietermaritzburg.

Warren, C., 2001, Matthew and empire: Initial explorations, Trinity Press, Harrisburg. 